American Journal of Animal and Veterinary Sciences 6 (1): 25-30, 2011

ISSN $1557-4555$

(C) 2011 Science Publications

\title{
Extrusion of Peas (Pisum sativum L.): Effects on the Apparent Metabolisable Energy and Ileal Nutrient Digestibility of Broilers
}

\author{
${ }^{2}$ Catootjie L. Nalle, ${ }^{2}$ Ganesharanee Ravindran and ${ }^{1}$ Velmurugu Ravindran \\ ${ }^{1}$ Institute of Food, Nutrition and Human Health, Massey University, \\ Private Bag 11 222, Palmerston North 4442, New Zealand \\ ${ }^{2}$ Department of Animal Husbandry, Polytechnic of Agriculture, \\ Nusa Tenggara Timur, Indonesia
}

\begin{abstract}
Problem statement: The potential feeding values of grain legumes, such as peas (Pisum sativum), are limited because of the presence of anti-nutritional factors. In particular, protease inhibitors are of interest, but these can be readily destroyed by thermal treatments. In the present study, the influence of extrusion on the chemical composition and nutritive value of peas was evaluated. Approach: Two extrudates were produced by extruding the peas at two moisture levels (19 and 22\%) and one temperature $\left(140^{\circ} \mathrm{C}\right)$. Four treatment diets consisting of a corn-soy basal diet and three test diets containing raw and the two extruded pea meals were formulated and assayed in digestibility and balance trials using broiler chickens. The test diets were formulated by substituting the raw and extruded pea meals for $25 \%(\mathrm{w} / \mathrm{w})$ of the basal diet. Ileal nutrient digestibility was calculated using titanium oxide as an indigestible indicator and the apparent metabolisable energy was determined using the classical total excreta collection method. Results: Extrusion had no effect $(\mathrm{P}>0.05)$ on the contents of crude protein and starch. Soluble non-starch polysaccharide contents were increased $(\mathrm{P}<0.05)$ and the contents of total and insoluble non-starch polysaccharide were lowered $(\mathrm{P}<0.05)$ by extrusion. As expected, trypsin inhibitor activity of peas was reduced $(\mathrm{P}<0.05)$ following extrusion Extrusion increased $(\mathrm{P}<0.05)$ the apparent ileal starch digestibility, but had no effect $(\mathrm{P}>0.05)$ on the apparent ileal protein digestibility and the apparent metabolisable energy of peas. Conclusion: Under the extrusion conditions employed in the present study, extrusion was not beneficial to improving the nutritive value of peas for broilers.
\end{abstract}

Key words: Extrusion cooking, nutrient digestibility, protein digestibility, starch digestibility, antinutritional factors, thermal treatments, pisum sativum

\section{INTRODUCTION}

Extrusion cooking is a high-temperature, shorttime process in which moistened, expansive, starchy and/or proteinacious food materials are plasticised and cooked in a tube by a combination of moisture, pressure, temperature and mechanical shear, resulting in molecular transformation and chemical reactions (Havck and Huber, 1989; Castells et al., 2005). This technology has some unique positive features compared with other heat processes, because the material is subjected to intense mechanical shear. It is able to break the covalent bonds in biopolymers and the intense structural disruption and mixing facilitate the modification of functional properties of food ingredients and/or texturizing them (Asp and Bjorck, 1989; Carvalho and Mitchelle, 2000). In addition, the extrusion process denatures undesirable enzymes; inactivates some antinutritional factors (trypsin inhibitors, haemagglutinins, tannins and phytates); sterilises the finished product; and retains natural colours and flavours of foods (Fellows, 2000; Bhandari et al., 2001). The process has found numerous applications.

Extrusion cooking is a process where the feed is subjected to mixing, shearing and heating under high pressure before the extrudate is forced through a die. During this process, the feed may undergo reactions which could be beneficial, if nutrient availability is improved or detrimental if nutrients are destroyed or altered to become resistant to digestion. Extrusion may influence the nature of feed components by changing physical (e.g., particle size), chemical (e.g., starch gelatinization, inactivation of anti nutrients) and nutritional (e.g., nutrient digestibility) properties (Björk and Asp, 1983; Riaz, 2000; Purushotham et al., 2007; Domoney and Welham, 1992). In addition, appropriate processing temperature is critical for the elimination of heat-labile anti-nutritional factors found in legume

Corresponding Author: Velmurugu Ravindran, Institute of Food, Nutrition and Human Health, Massey University, Private Bag 11 222, Palmerston North 4442, New Zealand Tel: +64 63505528 Fax +64 63505684 
seeds. Extrusion has been to shown to have positive effects on the in vitro digestibility of protein (Alonso et al., 2000a; 200b; El-Hady and Habiba, 2002) and the in vivo digestibility of fat (Danicke et al., 1998; Lichovnikova et al., 2004), amino acids (Lichovnikova et al., 2004) and starch (Alonso et al., 2000b) in diets for poultry. These improvements have been attributed to due to the reduction of anti-nutritional factors, denaturation of native protein and gelatinisation of starch.

Grain legumes, such as peas (Pisum sativum), are widely available in many parts of the world. These legumes are important protein sources in both human and animal nutrition (Nalle et al., 2010). However, their use in poultry feed industry remains limited because of the presence of anti-nutritional factors which interfere with nutrient utilisation resulting in poor animal performance. Of the various anti-nutritional factors present in grain legumes, protease inhibitors are of particular interest, but these components are readily destroyed by thermal treatments. The purpose of the study reported herein was to examine the effects of extrusion cooking on the chemical composition, ileal digestibility of protein and starch and apparent metabolisable energy (AME) of peas for broiler chickens

\section{MATERIALS AND METHODS}

Processing: Round seeded peas, purchased from a commercial supplier, were ground in a hammer mill to pass through a $3 \mathrm{~mm}$ sieve and then extruded in a twinscrew co-rotating self wiping extruder Clextral BC 21 (Firminy Cedex, France) with length/diameter ratio of 25 , screw speed up to $600 \mathrm{rpm}$ and outer screw diameter of $25 \mathrm{~mm}$. The screw configuration from feed section to die consisted of three sections with forward elements. The first section had 4 elements (each $50 \mathrm{~mm}$ length with 3 screw flights and $13 \mathrm{~mm}$ pitch); the second zone consisted 5 elements (each $50 \mathrm{~mm}$ in length having 4 screw flights and $10 \mathrm{~mm}$ pitch); and the third zone had 5 elements (each $50 \mathrm{~mm}$ in length with 6 screw flights and $7 \mathrm{~mm}$ pitch) The total length of the screw was $700 \mathrm{~mm}$ with 14 elements in three zones. The extruder was equipped with a bulk solids metering feeder (KTRON T20, Switzerland). A round die (3.0 $\mathrm{mm}$ diameter), equipped with a cutting device set at 130rpm, was used.

Extrusion of peas was performed at two moisture levels (19 and $22 \%)$ and one temperature $\left(140^{\circ} \mathrm{C}\right)$. These processing conditions were selected since these were found to show the best nutritional properties in a previous in vitro evaluation in our laboratory. The desired moisture levels were obtained by adding water prior to the extruder section by means of a pump. The water feed rate for obtaining the final moisture content of $19 \%$ was 0.50 , while $0.75 \mathrm{~kg} \mathrm{~h}^{-1}$ was used to achieve
$22 \%$ final moisture content. The optimum temperatures of the seven extruder sections from the feeder end were $50,60,70,80,100,100$ and $140^{\circ} \mathrm{C}$. The extruded materials were then allowed to cool to room temperature. The raw and extruded peas were ground in a hammer mill to pass through a $3 \mathrm{~mm}$ sieve.

Experimental design: The experimental procedures were approved by the Massey University Animal Ethics Committee. Four treatment diets consisting of a cornsoy basal diet (Table 1) and three test diets containing raw and extruded pea meals were assayed. The test diets were formulated by substituting the raw and extruded pea meals for $25 \%(\mathrm{w} / \mathrm{w})$ of the basal diet. All diets contained titanium oxide $\left(3 \mathrm{~g} \mathrm{~kg}^{-1}\right)$, as an indigestible marker as an indigestible marker to calculate the nutrient digestibility.

Day-old male broilers (Ross 308) were raised in floor pens and fed a commercial broiler starter diet (23 $\%$ crude protein) till day 21 . Feed and water were available at all times. On day 21, 64 birds of uniform body weight were selected and randomly assigned to 16 cages ( 4 birds per cage). The birds were offered a commercial broiler finisher diet (18\% crude protein) until the introduction of assay diets, in mash form, on day 28 . On day 28 , four replicate cages were randomly assigned to each assay diet.

The AME was determined using the classical total excreta collection method. Feed intake and excreta output were measured quantitatively per cage from day 32 for four consecutive days. The excreta from each cage were pooled, mixed, sub-sampled and freezedried. The dried excreta samples, together with samples of the diets, were subsequently ground to pass through $0.5-\mathrm{mm}$ sieve and stored in airtight plastic containers for analysis of dry matter and gross energy.

Table 1: Composition ( $100^{-1} \mathrm{~g}$ as fed) of the basal diet used in metabolisable energy and digestibility assays

\begin{tabular}{lc}
\hline Ingredient & 594.6 \\
\hline Corn & 351.8 \\
Soybean meal & 17.8 \\
Soybean oil & 21.7 \\
Dicalcium phosphate & 7.8 \\
Limestone & 2.0 \\
Salt & 2.3 \\
Sodium bicarbonate & 3.0 \\
Trace mineral-vitamin premix ${ }^{1}$ & \\
\hline Provided per kg diet: Co, 0.3 mg; Cu, $5 \mathrm{mg} ;$ Fe, $25 \mathrm{mg} ; \mathrm{I}, 1 \mathrm{mg} ; \mathrm{Mn}$, \\
$125 \mathrm{mg}$; Zn, $60 \mathrm{mg}$; choline chloride, $638 \mathrm{mg}$; trans-retinol, $3.33 \mathrm{mg} ;$ \\
cholecalciferol, $60 \mu \mathrm{\mu g}$; dl- $\alpha$-tocopheryl acetate, $60 \mathrm{mg}$; menadione, 4 \\
mg; thiamin, $3.0 \mathrm{mg}$; riboflavin, $12 \mathrm{mg}$; niacin, 35 mg; calcium \\
panthothenate, $12.8 \mathrm{mg}$; pyridoxine, $10 \mathrm{mg}$; cyanocobalalamin, 0.017 \\
mg; folic acid $5.2 \mathrm{mg}$; biotin, $0.2 \mathrm{mg}$; antioxidant, $100 \mathrm{mg}$; \\
molybdenum, $0.5 \mathrm{mg}$; selenium, $200 \mu \mathrm{gg}$
\end{tabular}


On day 35, all birds were euthanised by an intracardial injection of sodium pentobarbitone solution and the contents of the lower half of the ileum were collected and processed as described by Ravindran et al. (2005; 2009). The diet and digesta samples were then analysed for dry matter, titanium oxide, starch and nitrogen.

Chemical analysis: All analyses were conducted in triplicates and the results are reported on a dry matter basis. The dry matter, crude fat and ash contents were determined according to AOAC et al. (2010). Nitrogen content was determined by the combustion method (AOAC et al., 2010) using a CNS-2000 carbon, nitrogen and sulphur analyzer $\left(\mathrm{LECO}^{\circledR}\right.$ Corporation, St. Joseph, Michigan, USA). The crude protein content of the samples was calculated by multiplying the nitrogen content by 6.25 . Gross energy was determined using an adiabatic oxygen calorimeter (Gallenkamp Autobomb, London, UK) standardized with benzoic acid.

Starch content was measured using an assay kit (Megazyme, Boronia, VIC, Australia) based on the use of thermostable $\alpha$-amylase and amyloglucosidase. Total, soluble and insoluble non-starch polysaccharides (NSP) were determined using an assay kit (Englyst Fiberzyme Kit GLC, Englyst Carbohydrate Services Limited, Cambridge, UK). The titanium oxide content was measured using the colorimetric method described by Short et al. (1996). The procedure to determine trypsin inhibitor. Trypsin inhibitor activity was expressed in units of trypsin inhibited (TIU) per milligram sample.

Calculations: The AME values of the test diets and pea samples were calculated using the following formulas:

$$
\begin{gathered}
\left(\text { Feed int ake } \times \mathrm{GE}_{\text {diet }}\right) \\
\mathrm{AME}_{\text {diet }}\left(\mathrm{MJ} \mathrm{kg}^{-1}\right)=\frac{-\left(\text { Excreta output } \times \mathrm{GE}_{\text {extrecta }}\right)}{\text { Total feed int ake }}
\end{gathered}
$$$$
\begin{gathered}
\text { AME of pea diet } \\
\mathrm{AME}_{\text {peas }}\left(\mathrm{MJ} \mathrm{kg}^{-1}\right)=\frac{-(\text { AME basal diet } \times 0.75)}{0.25}
\end{gathered}
$$

The apparent ileal digestibility coefficient (AIDC) of nitrogen and starch in the test diets and pea samples were calculated, using titanium oxide as the indigestible marker, as shown below:

$$
\text { AIDC of pea diet }=\frac{(\text { Nutrient } / \mathrm{Ti} / \mathrm{d})-(\text { Nutrient } / \mathrm{Ti}) \mathrm{i}}{(\text { Nutrient } / \mathrm{Ti}) \mathrm{d}}
$$

(AIDC of pea diet $\times$ Nutrient in pea diet)

- (AIDC of basal diet $\times 0.75$

AIDC of peas $=\frac{\times \text { nutrient in the of basal diet })}{0.25 \times \text { Nutrient in peas }}$

Where:

(Nutrient/Ti)d $=$ Ratio of nutrient and titanium in diet

$($ Nutrient $/ / T i) i=$ Ratio of nutrient and titanium in ileal digesta

Statistical analysis: The data were analysed by oneway analysis of variance using the General Linear Model procedure of SAS with cage as the experimental unit. Differences were considered to be significant at $\mathrm{P}<0.05$ and significant differences between means were separated by the Fisher's Least Significant Difference test.

\section{RESULTS AND DISCUSSION}

The results showed that extrusion cooking of peas had no effect $(\mathrm{P}<0.05)$ on the contents of crude protein, crude fat and ash of the extrudates (Table 2). The lack of effect of extrusion on the fat and ash contents of peas is in agreement with the findings of Alonso et al. (1998). In contrast, Diaz et al. (2006) reported that the fat and ash contents of peas were increased by 61 and 4\%, respectively, following extrusion. The observed discrepancy is likely to be due to the differences in the extruder type used. In the present study, a twin-screw extruder type was used, whilst in the study by Diaz et al. (2006), a singlescrew extruder type was used. As reported by Björk and Asp (1983), the type of extruder is a critical factor which will affect the degree of modification in nutritional properties. Extrusion conditions are also important, but it was difficult to compare the effects of this aspect, because Diaz et al. (2006) did not describe the conditions used in their study.

Extrusion significantly $(\mathrm{p}<0.05)$ influenced the NSP contents of peas (Table 2). Soluble NSP contents were increased $(p<0.05)$ and the contents of total and insoluble NSP were lowered $(\mathrm{p}<0.05)$ by extrusion. The increase in soluble NSP with extrusion was in agreement with previous studies (Vasanthan et al., 2002) and this may be attributed to the conversion of part of the insoluble NSP to soluble NSP. 
American J. Animal \& Vet. Sci., 6 (1): 25-30, 2011

Table 2: The effect of extrusion the chemical composition ( $\mathrm{g} / 100 \mathrm{~g}$ dry matter) of peas

\begin{tabular}{|c|c|c|c|c|c|}
\hline & Raw, Unextruded & $\begin{array}{l}\text { Extruded, } 19 \% \\
\text { moisture, } 140^{\circ} \mathrm{C}\end{array}$ & $\begin{array}{l}\text { Extruded, } 22 \% \\
\text { moisture, } 140^{\circ} \mathrm{C}\end{array}$ & Pooled SEM & Probability \\
\hline Crude protein & 23.00 & 22.60 & 22.90 & 0.880 & NS \\
\hline Crude fat & 2.50 & 2.50 & 2.60 & 0.210 & NS \\
\hline Ash & 3.10 & 3.10 & 3.10 & 0.160 & NS \\
\hline Starch & 46.50 & 46.00 & 46.10 & 1.120 & NS \\
\hline \multicolumn{6}{|l|}{ Non starch polysaccharides } \\
\hline Soluble & $2.30^{\mathrm{a}}$ & $2.50^{\mathrm{b}}$ & $2.80^{\mathrm{c}}$ & 0.160 & $* *$ \\
\hline Insoluble & $17.70^{\mathrm{a}}$ & $17.20^{\mathrm{b}}$ & $16.60^{\mathrm{c}}$ & 0.170 & $*$ \\
\hline Total & $20.00^{\mathrm{a}}$ & $19.70^{\mathrm{b}}$ & $19.40^{\mathrm{c}}$ & 0.080 & $*$ \\
\hline Trypsin inhibitor activity (TIU/mg) & $0.23^{\mathrm{a}}$ & $0.25^{\mathrm{a}}$ & $0.19^{\mathrm{b}}$ & 0.004 & $*$ \\
\hline
\end{tabular}

Table 3: The effect of extrusion on the apparent metabolisable energy (AME, MJ/kg dry matter) and Apparent Ileal Digestibility Coefficient (AIDC) of protein and starch of peas for broilers

\begin{tabular}{llllll}
\hline & & Extruded, $19 \%$ & Extruded, $22 \%$ & \\
& Raw, Unextruded & moisture, $140^{\circ} \mathrm{C}$ & moisture, $140^{\circ} \mathrm{C}$ & Pooled SEM & Probability \\
\hline AME & 11.7 & 11.1 & 11.1 & 0.45 & NS \\
AIDC of protein & 0.828 & 0.838 & 0.803 & 0.0912 & NS \\
AIDC of starch & $0.865^{\mathrm{a}}$ & $1.015^{\mathrm{b}}$ & $0.986^{\mathrm{b}}$ & 0.0321 & $* *$ \\
\hline a,b : Means in a row with different superscripts differ $(\mathrm{p}<0.05) ;$ NS: Not Significant $(\mathrm{p}>0.05) ;{ }^{* *}$ : Significant at $\mathrm{p}<0.01 ;{ }^{1}:$ Each value represents
\end{tabular}
the mean of four replicates (4 birds/replicate)

In this evaluation, extrusion cooking had no effect $(\mathrm{p}<0.05)$ on the starch content (Table 2). This finding is in disagreement with those of Diaz et al. (2006) who showed a decrease in the starch content of peas extruded with a single-screw extruder. This variability was probably due to the difference in methodology, especially the type of extruder used. Perez-Navarrete et al. (2006) also reported a decrease in the starch content of extruded products and attributed this observation to the formation of indigestible starch, which makes it difficult to be extracted by enzymes used in the analysis of starch.

The reduction in trypsin inhibitor activity of peas following extrusion (Table 2) was an expected result and in agreement with previous research (van der Poel, 1992; O’Doherty and Keady, 2001; Diaz et al., 2006). In the study by Van der Poel (1992), the trypsin inhibitor activity of pea cultivars (round- and wrinkle seeded peas) were reduced by extrusion at different processing temperatures $\left(106-140^{\circ} \mathrm{C}\right)$ and moisture contents (14-33\%). However, the degree of inactivation was dependent on the processing conditions and the cultivar used. The inactivation of trypsin inhibitor activity in round-seeded peas was almost complete under the different processing conditions investigated, whereas the trypsin inhibitor activity in wrinkle-seeded pea was inactivated only at the highest temperature.

Ileal nutrient digestibility: Extrusion had no effect on the AIDC of protein in peas (Table 3). It is possible that the lack of improvement in the protein digestibility of pea protein after heat treatment could be due to protein aggregation (Meng et al., 2002; Carbonaro et al., 2005) and non-enzymatic browning-thermal cross-linking caused by Maillard reaction (Vasanthan et al., 2002).

The improvements observed in ileal starch digestibility in pea extrudates (Table 3) was as expected. The improvement of starch digestibility after extrusion was likely to be due to gelatinisation which increases the accessibility of starch to digestive enzymes. Native granule starch, which consists predominantly of $\alpha$-glucan in the form of amylose and amylopectin, is hydrolysed slowly by $\alpha$-amylase and amyloglucosidase compared with gelatinised starch in processed foods. When native starches are heated in excess water, the crystalline structure is disrupted and water molecules form hydrogen bonds to the exposed hydroxyl groups of amylose and amylopectin (Ratnayake et al., 2002; Tester et al., 2004). This causes an increase in granule swelling and solubility. Granule structure is completely lost, making the starch to be completely digested by starch-hydrolysing enzymes.

Curiously, ileal starch digestibility in the 19\% $140^{\circ} \mathrm{C}$ treatment was calculated to exceed $100 \%$. This error may be due to the method of determination employed. The substitution method was used in the present study in order to calculate ileal digestibility. This method assumes that there is no interaction between the basal diet and the test ingredient (Ravindran and Bryden, 1999; Lemme et al., 2004), but which may not be the case.

Apparent metabolisable energy: In the present study, extrusion cooking had no effect on the AME of peas (Table 3). In contrast, Breytenbach (2005) reported that the AME value of Australian sweet lupin decreased (8.61 and $7.52 \mathrm{MJ} \mathrm{kg}^{-1}$ ) after extrusion with a single- 
screw extruder at a barrel jacket temperature of $120^{\circ} \mathrm{C}$. The observed decrease was attributed to the increased bulkiness that occurred during expansion which leads to reduced feed and energy intakes. In contrast, Prinsloo (1993, cited by Breytenbach, 2005) demonstrated that the AME value of Australian sweet lupins for adult cockerels was increased by $11.5 \%$ (6.71 and $7.58 \mathrm{MJ}$ $\mathrm{kg}^{-1}$ ) by extrusion with a barrel temperature of $120^{\circ} \mathrm{C}$. These findings suggest that the extent of changes in the nutritional value of a feed ingredient via extrusion was dependent on the type of extruder, processing condition, type of ingredient and class of chicken.

It is noteworthy that although the ileal starch digestibility of peas markedly increased after extrusion, the AME values were unaffected. It is difficult to provide a reason for these observations. Starch digestibility was determined at the ileal level, whereas the AME was determined at the excreta level and this may provide some explanation. It is well documented that microbial activity in the hindgut of chickens has a marked influence on the utilisation of nutrients (Ravindran et al., 1999).

\section{CONCLUSION}

In summary, under the extrusion conditions employed in the current study, extrusion cooking had no effect on the protein and fat contents of peas, but resulted in increased soluble NSP contents. Extrusion had no effect on the ileal protein digestibility of peas for broiler chickens, but increased the ileal starch digestibility of peas. However, improvements in starch digestion failed to translate into any beneficial effect in terms of AME in peas for broilers. It is concluded that, under the conditions of the present study, extrusion cooking was not beneficial to improve the nutritive value of peas for broilers.

\section{ACKNOWLEDGEMENT}

This project was partly supported by the sustainable farming fund (SFF) of the Ministry of Agriculture and Forestry, Wellington. The SSF project funding and reporting are facilitated through the Foundation of Arable Farming (FAR). The assistance of Jacqui Johnston of FAR is gratefully acknowledged.

\section{REFERENCES}

Alonso, R., A. Aguirre and F. Marzo, 2000a. Effects of extrusion and traditional processing methods on antinutrients and in vitro digestibility of protein and starch in faba and kidney beans. Food Chem., 68: 159-165. DOI: 10.1016/S0308-8146(99)00169-7
Alonso, R., G. Grant, P. Dewey and F. Marzo, 2000b. Nutritional assessment in vitro and in vivo of raw and extruded peas (Pisum sativum L.). J. Agric. Food Chem., 48: 2286-2290. DOI: 10.1021/jf000095o

Alonso, R., E. Orúe and F. Marzo, 1998. Effects of extrusion and conventional processing methods on protein and antinutritional factor contents in pea seeds. Food Chem., 63: 505-512. DOI: 10.1016/S0308-8146(98)00037-5

AOAC, Int., W. Horwitz and G.W. Latimer, 2010. Official Methods of Analysis of AOAC International. 18th Edn., AOAC International, ISBN-10: 0935584803

Breytenbach, L., 2005. The influence of processing of lupins and canola on apparent metabolizable energy and broiler performance. $\mathrm{PhD}$ Thesis. Stellenbosch University, Stellenbosch, South Africa. http://scholar.sun.ac.za/handle/10019.1/2200

Carbonaro, M., G. Grant and M. Cappelloni, 2005. Heat-induced denaturation impairs digestibility of legume (Phaseolus vulgaris L and Vicia faba L) 7S and $11 \mathrm{~S}$ globulins in the small intestine of rat. J. Sci. Food Agric., 85: 65-72. DOI: $10.1002 /$ jsfa. 1940

Danicke, S., W. Kracht, H. Jeroch, R. Zachmann and E. Heidenreich et al., 1998. Effect of different technical treatments of rapeseed on the feed value for broilers and laying hens. Arch. Anim. Nutr., 51: 53-62. DOI: 10.1080/17450399809381905

Diaz, D., M. Morlacchini, F. Masoero, M. Moschini and G. Fusconi et al., 2006. Pea seeds (Pisum sativum), faba beans (Vicia faba var. minor) and lupin seeds (Lupinus albus var. multitalia) as protein sources in broiler diets: Effect of extrusion on growth performance. Italian J. Anim. Sci., 5: 43-53. http://digitalcommons.usu.edu/advs_facpub/244/

Domoney, C. and T. Welham, 1992. Trypsin inhibitors in Pisum: variation in amount and pattern of accumulation in developing seed. Seed Sci. Res., 2: 147-154. DOI: 10.1017/S0960258500001276

El-Hady, E.A.A. and R.A. Habiba, 2003. Effect of soaking and extrusion conditions on antinutrients and protein digestibility of legume seeds. Lebensmittel-Wissenchaft und-Technol., 36: 285293. DOI: 10.1016/S0023-6438(02)00217-7

Lemme, A., V. Ravindran and W.L. Bryden, 2004. Ileal digestibility of amino acids in feed ingredients for broilers. Wld's Poult. Sci. J., 60: 423-438. DOI: 10.1079/WPS200426 
Lichovnikova, M., L. Zeman, S. Kracmar and D. Klecker, 2004. The effect of the extrusion process on the digestibility of feed given to laying hens. Anim. Feed Sci. Technol., 116: 313-318. DOI: 10.1016/j.anifeedsci.2004.07.018

Meng, G.T., K.M. Ching and C.Y. Ma, 2002. Thermal aggregation of globulin from an indigenous Chinese legume, Phaseolus angularis (red bean). Food Chem., 79: 93-103. DOI: 10.1016/S03088146(02)00184-X

Nalle, C.L., V. Ravindran and G. Ravindran, 2010. Evaluation of faba beans, white lupins and peas as protein sources in broiler diets. Int. J. Poult. Sci., 9: 567-573. http://www.pjbs.org/ijps/fin1721.pdf

O'Doherty, J.V. and U. Keady, 2001. The effect of expander processing and extrusion on the nutritive value of peas for pigs. Anim. Sci., 72: 43-53.

Pérez-Navarrete, C., R. Gonzáles, L. Chel-Guerrero and D. Betancur-Ancona, 2006. Effect of extrusion on nutritional quality of maize and lima bean flour blends. J. Sci. Food Agric., 86: 2477-2484. DOI: 10.1002 jsfa.2661

Purushotham, B., P.M. Radhakrishna and B.S. Sherigara, 2007. Effects of steam conditioning and extrusion temperature on some anti-nutritional factors of soyabean (glycine max) for pet food applications. Am. J. Anim. Vet. Sci., 2: 1-5. DOI: 10.3844/ajavsp.2007.1.5

Ratnayake, W.S., R. Hoover and T. Warkentin, 2002. Pea Starch: composition, structure and propertiesA review. Starch/Stärke, 54: 217-234. DOI: 10.1002/1521-379X(200206)54:6<217::AIDSTAR217>3.0.CO;2-R

Ravindran, V. and W.L. Bryden. 1999. Amino acid availability in poultry-in vitro and in vivo measurements. Aust. J. Agric. Res., 50: 889-908. http://ses.library.usyd.edu.au/bitstream/2123/2276/ 1/Ravindran_V._and_Bryden_W.L._1999.pdf
Ravindran, V., L.I. Hew, G. Ravindran and W.L. Bryden, 2005. Apparent ileal digestibility of amino acids in dietary ingredients for broiler chickens. Anim. Sci., 81: 85-97. DOI: 10.1079/ASC42240085

Ravindran, V., L.I. Hew, G.Ravindran and W.L. Bryden, 1999. A comparison of ileal digesta and excreta analysis for the determination of amino acid digestibility in food ingredients for poultry. Brit. Poult. Sci., 40: 266-274. DOI: 10.1080/00071669987692

Ravindran, V., P.C.H.. Morel, S.M. Rutherfurd and D.V. Thomas, 2009. Endogenous flow of amino acids in the avian ileum as increased by increasing dietary peptide concentrations. Brit. J. Nutr., 101: 822-828. DOI: 10.1017/S0007114508039974

Riaz, M.N., 2000. Extruders in Food Applications. $1^{\text {st }}$ Edn., Technomic Pub. Co., USA., ISBN-10: 1566767792, pp: 223.

Short, F.J., P. Gorton, J. Wiseman and K.N. Boorman, 1996. Determination of titanium dioxide added as an inert marker in chicken digestibility studies. Anim. Feed Sci. Technol., 59: 215-221. http://www.journals.elsevierhealth.com/periodicals /anifee/article/PII0377840195009167/abstract

Tester, R.F., J. Karkalas and X. Qi, 2004. Starch structure and digestibility enzyme-substrate relationship. Wld's Poult. Sci. J., 60: 186-195. DOI: $10.1079 /$ WPS200312

van der Poel, A.F.B., 1992. Twin-screw extrusion of two pea varieties: Effects of temperature and moisture level on antinutritional factors and protein dispersibility. J. Sci. Food Agric., 58: 83-87. DOI: $10.1002 /$ jsfa.2740580114

Vasanthan, T., J. Gaosong, J. Yeung and J. Li, 2002. Dietary fiber profile of barley flour as affected by extrusion cooking. Food Chem., 77: 35-40. DOI: 10.1016/S0308-8146(01)00318-1 